\title{
Quarenta anos de formatura
}

Octavio M. Guimarães

Meus companheiros de 1909.

Relendo a profissão de fé que tive a honra de fazer em nome dos bacharelandos de 1909, com a jatância e o alarde dos que ainda ignoram, notei que quase nada havia mudado nos sentimentos e nas idéias que então se expressaram.

A sensação amarga do afastamento a que se referiu, foi sempre a mesma nas outras separações a que a vida nos forçou, por essa adaptação profunda do homem ao ambiente em que viveu, e às raízes a que se prendeu.

$O$ interêsse também de cada um de nós pelo companheiro de vida que aí se ressaltou, continuou idêntico ao que era, pôsto que mais ativo e mais fecundo, porque mais compreendido.

A dôr que era nesse tempo quase que só idéia, ou representação abstrata, mais tarde, quando a vida nos envolveu, tornou-se realidade, e intrometemos no nosso todos os seres que como nós também padeciam e sangravam.

Nem a linguagem que então falavamos se diferenciou. E ainda a mesma que era, embora baixasse o seu tom, e ganhasse o equilíbrio que não podia possuir no tempo desordenado e tumultuoso da primavera que se abria.

$\mathrm{E}$ agora, nessa raia divisória entre a vida que subiu e a vida que está descendo, podemos nos envaidecer de haver mantido o mesmo ímpeto inicial, e de sermos ainda aquilo que eramos há quarenta anos, na espontaneidade dos nossos sentimentos, na bravura dos nossos atos e no 
afeto que então nos congraçava e até agora ainda nos une.

Nosso pensamento também não se alterou, sem embargo da extensão que os anos lhe deram.

Em 1909 diziamos o que ainda hoje dizemos, isto é, que o direito não poderia ser uma ciência abstrata, criada para seres imaginários, mas, lidando com a pessoa humana, teria que embeber-se também da sua carne e do seu sangue, e refletir essas necessidades reais e palpitantes.

Se os dons não são iguais, e se há possibilidade de que, indominado ou sem freios, se desencandeiem os instintos de ganho de prêsa, é preciso que a lei intervenha, e sem ferir a personalidade humana, refreie essas fôrcas inferiores, para que todos os homens, dentro de um limite mínimo, usufruam também os benefícios ou as regalias da vida.

No alvorecer assim sentimos e assim pensamos; e dai em diante foi essa a inspiração da nossa conduta. Tivemos os primores da juventude, seus sorrisos e seus estrépitos; Passou para nós êsse tempo de agitação e de florescência; e nos veio o outono com as suas colheitas. Chegou a hora da madureza, da reflexão, do sol a pino, das vozes altas e solenes. Vem vindo agora o remanso das águas que se agitaram; o momento repousado em que o homem conhece a insanidade da ambição que se desmede, a esterilidade da luta que se desenfreia e se reconcilia por fim com a pequenez e a fragilidade de sua vida.

Está se extinguindo no homem que envelhece, o que havia de agreste na sua feição, de duro no seu trato, de conturbado nas suas ações, para sobreviver sòmente a porção límpida, a essência do pensamento ou de uma pureza que não desaparecerão.

Aqui estamos, não todos, porque a morte incansável ceifou larga e tristemente o nosso grupo; não como eramos, com aquela alacridade e aquêles planos imensos dos primeiros anos, mas todos já marcados pela vida, e já defini- 
dos, mais alto uns, mais baixo outros, mas todos iguais no mesmo afeto fraternal dos que sempre se quiseram.

De ora em diante teremos que caminhar mais juntos ainda, porque as fileiras que se rareiam, querem uma vinculação mais apertada dos que continuam.

E prosseguiremos com a sabedoria que a vida já nos deu, com a alegria dos que se conformam, porque já conheceram que o nosso quinhão nem bom nem mau, é a sorte comum de todos os homens, e essa igualdade nos afaz à desigualdade de cada um. Agradeçamos; pois, ao Senhor de tôdas as graças, a vida que nos deu e nos conservou; a relativa abastança com que nos libertou da amargura da dependência; e agora, sobretudo, a alegria dos olhos que vêem e o contentamento das almas que encontraram a paz.

Meus amigos e meus colegas: - que o meu abraço nos continue a ajuntar no calor que sempre nos aqueceu. 